\title{
THE RESPONSE OF SPINACH (SPINACIA OLERACIA L.) PHYSIOLOGICAL CHARACTERSTICS TO DIFFERENT BIOCHAR TREATMENTS UNDER SALINE CONDITION
}

\author{
SOOTHAR, M. K..$^{1,2}$ - ABDOUL KADER, M. H. ${ }^{1}$ - SOOTAHAR, M. K. ${ }^{2,3}-$ YANG, G. $^{1}$ - ZAIN, M. ${ }^{1}$ - \\ SUN, J. ${ }^{1 *}-$ PANHWAR, A. A. ${ }^{2,4}$ \\ ${ }^{1}$ Key Laboratory for Crop Water Requirement and Regulation of Ministry of Agriculture, \\ Farmland Irrigation Research Institute, CAAS, Xinxiang, Henan 453003, China \\ ${ }^{2}$ Department of Soil Science, Sindh Agriculture University, Tandojam 70060, Pakistan \\ ${ }^{3}$ Institute of Environment and Sustainable Development in Agriculture, CAAS, Beijing 100081, \\ China \\ ${ }^{4}$ National Key Laboratory of Crop Genetic Improvement Microelement Research Center, \\ Huazhong Agricultural University, Wuhan, China \\ *Corresponding author \\ e-mail: jshsun623@163.com \\ (Received $26^{\text {th }}$ Nov 2020; accepted $3^{\text {rd }}$ Mar 2021)
}

\begin{abstract}
Biochar is considered beneficial for plant growth and soil properties under saline condition. A pot experiment was conducted to investigate the effect of acidic biochar on physiological and growth parameters, as well as nutrient concentration of spinach. Five treatments were arranged; Control (CK) without biochar and salt application, Wood Biochar (WB), WB0, WB1, WB2 and WB3 with 0, 15, 30 and $45 \mathrm{~g} \mathrm{~kg}^{-1}$ biochar, respectively, $+1 \%$ salt. Physiological characteristics and growth parameters and total nitrogen (TN) and phosphorus (TP) were determined on 48 and 50 days after sowing respectively. The results showed that the number of leaves, plant height and fresh and dry weights decreased by 58.1, 53.1 and 82.7 and $81.3 \%$, respectively, in WB3 compared to CK. Physiological characteristics of spinach plants were negatively affected by addition of biochar. TN in spinach was lower in WB3 than CK. In contrast, TP uptake was enhanced by $93.8 \%$ in WB3 compared to CK. Moreover, biochar addition decreased soil $\mathrm{pH}$ and increased soil electrical conductivity (EC), TP and TN increased by 317.4 and $34.5 \%$, respectively in biochar treated soil. We conclude that further studies should be conducted to evaluate the effect of acidic biochar on other crops and soil properties.
\end{abstract}

Keywords: NP concentration, photosynthesis, saline condition, spinach growth, soil properties

\section{Introduction}

Accumulation of salts, ( $\mathrm{Na}, \mathrm{Ca}, \mathrm{K}, \mathrm{Cl}, \mathrm{SO}_{4}, \mathrm{Mg}$ ) in soil through application of lowquality irrigation water, anthropogenic activities, and climatic changes causes salinity in soil. Soil salinity adversely affects plants height, fresh and dry weight, growth and yield because of the total concentration of salts in the soil solution $\mathrm{Xu}$ and $\mathrm{Mou}, 2016$; Alagoz and Toorchi, 2018) which directly affects plants' physiological and biochemical characteristics, including the growth of root and shoot (Zhang et al., 2013), photosynthesis and respiration (Yang et al., 2020), soil microbes (Yan et al., 2015) and leads to wilting, or ultimately the death of the plant (Hamouda et al., 2015; Ahmad et al., 2016). $\mathrm{Na}$ and $\mathrm{Cl}$ at high concentrations are toxic to plants, especially when they increase in cytosol (Zorb et al., 2018). However, with the passage of time salt contents increase gradually in soil irrigated with salt water (Min et al., 2016). Final outcome as response to impure irrigation water on the metabolism of vegetables depends on the 
nature of the substance, the time of exposure and the ability of plants to adapt (Maksimovic and Ilin, 2012).

Vegetables are generally eaten as fresh or after cooking processes, are rich in phytochemicals, such as phenolics, vitamins, glucosinolates and anthocyanin with a beneficial impact on human health (Caparrotta et al., 2019). Spinach (Spinacia oleracia L.) is one of the important leafy vegetables which contain high amount of beta carotene, folate, vitamin $\mathrm{C}$, calcium, iron and oxygen radical absorbance capacity (Dicoteau, 2000). Spinach is considered as salt tolerant leafy vegetable, which can survive at ECe > $4.2 \mathrm{dS} \mathrm{m}^{-1}$ (Ors and Suarez, 2016). However, some studies reported that salinity (mainly $\mathrm{Na}$ and $\mathrm{Cl}$ ) depressed chlorophyll $a$, chlorophyll $b$ and protein (Ratnakar and Rai, 2013), increased osmotic and oxidative stress, nutritional imbalance and reduction in cell division (Zhu, 2003) which directly affect water consumption and fresh yield of spinach (Unlukara et al., 2017).

Many research studies have reported different strategies including organic and inorganic sources, have been applied to combat with salinity (Amini et al., 2016). Leaching of salts, replacement of $\mathrm{Na}$, use of gypsum, phytoremediation and organic matter application are most commonly methods of reclaiming these soils (Ding et al., 2010; Filho et al., 2019; Wichern et al., 2020). But those strategies did not remain effective. Biochar is recently one of the products received by pyrolysis of different organic materials (crop residue, animal or poultry waste) by heating at various temperatures. Biochar is highly recalcitrant due its high aromaticity and is able to sequester carbon for long time (Lehman and Joseph, 2009). Therefore, it has been used in agriculture on large scale since long time for various purposes, for example; it improves soil physical and chemical properties (Glab et al., 2016; Piash et al., 2019), increase plant available water storage capacity (Duarte et al., 2019), soil water holding capacity, permeability and aeration (Gavili et al., 2018; Huang et al., 2019; Danish et al., 2020), reclamation of saline soils (Amini et al., 2016) and increase yield of crops in saline soils (Lashari et al., 2013; Akhtar et al., 2015). It is reported in field and greenhouse experiments that biochar has positive impact on soil properties, field crops and vegetables under saline irrigation and drought conditions (Younis et al., 2015; Agbna et al., 2017; Huang et al., 2019). Furthermore, biochar is capable to improve soil organic matter and mineral NPK (Huang et al., 2019). A very little is known about the application of acidic biochar on vegetables. Because, generally alkaline $\mathrm{pH}$ biochars are used in the experiments (Lashari et al., 2013; Akhtar et al., 2015) and low pH (acidic) biochars are neglected. Thus, acidic biochar application could be a possible approach to increase spinach production under salinity stress. However, no study is reported in saline conditions with low $\mathrm{pH}$ biochar for spinach. The study aimed (i) to evaluate the effect of wood biochar on spinach physiological characters under saline condition, and (ii) to assess the effects of wood biochar application on soil properties and nutrient content under saline condition.

\section{Materials and methods}

\section{Experimental soil and salt analysis}

Surface soil layer $(0-20 \mathrm{~cm})$ used in the current experiment was taken from barren land of Alar city, Xinjiang province of China $\left(80^{\circ}, 50^{\prime} 19^{\prime \prime} \mathrm{E}\right.$ and $40^{\circ}, 27^{\prime} 17^{\prime \prime} \mathrm{N}$,). The soil was ground and passed through $2 \mathrm{~mm}$ sieve in order to remove gravels. Physico-chemical properties of soil were analyzed before starting the experiment as 
given in Table 1. Soil $\mathrm{pH}$ and electrical conductivity (EC) were measured in 1:5 w/v distilled water extract by using $\mathrm{pH}$ and EC meter (Fisher scientific, USA). For soil texture, hydrometer method was used (Bouyoucos, 1962); cation exchange capacity of soil was determined by ammonium acetate method (Rayment and Higginson, 1992), and total $\mathrm{N}$ and $\mathrm{P}$ were analyzed by elemental analyzer. The local salts collected from the same locality was analyzed for chemical properties; chloride, exchangeable potassium, sodium, calcium and magnesium before using for the experiment.

Table 1. Physio-chemical properties of soil and biochar used in the experiment

\begin{tabular}{c|c|c|c}
\hline Parameters & Soil & Biochar & Salt \\
\hline Texture & Silty clay loam & - & - \\
$\mathrm{Ph}$ & 8.51 & 2.52 & - \\
$\mathrm{EC} \mathrm{mS} \mathrm{cm}$ & -1 & - & - \\
$\mathrm{CEC} \mathrm{cmol}(+) \mathrm{kg}^{-1}$ & 3.31 & 23.7 & - \\
Total Nitrogen $\left(\mathrm{mg} \mathrm{g}^{-1}\right)$ & 3.86 & 2.8 & - \\
Total Phosphorus $\left(\mathrm{mg} \mathrm{g}^{-1}\right)$ & 0.50 & 64.9 & - \\
Total Potassium $\left(\mathrm{mg} \mathrm{g}^{-1}\right)$ & 0.66 & 5.6 & - \\
Chloride $\left(\mathrm{g} \mathrm{kg}^{-1}\right)$ & - & 0.03 & 70.0 \\
Exchangeable K $\left(\mathrm{g} \mathrm{kg}^{-1}\right)$ & 7.10 & - & 0.02 \\
Exchangeable Na $\left(\mathrm{g} \mathrm{kg}^{-1}\right)$ & - & 0.50 & 4.46 \\
Exchangeable Ca $\left(\mathrm{g} \mathrm{kg}^{-1}\right)$ & 0.18 & - & 0.04 \\
Exchangeable $\mathrm{Mg}\left(\mathrm{g} \mathrm{kg}^{-1}\right)$ & 50.43 & - & 1.94 \\
\hline
\end{tabular}

$\mathrm{n}=3, \mathrm{EC}=$ Electrical conductivity, $\mathrm{CEC}=$ Cation exchange capacity

\section{Biochar and its characterization}

Wood biochar (WB) used in this experiment was prepared by pyrolysis of wood at approximately $250-300{ }^{\circ} \mathrm{C}$ in oxygen free kiln (Shangqiu SanLi Company, Henan province, China). The method proposed by $\mathrm{Li}$ et al. (2016) was used for the determination of $\mathrm{pH}$ of biochar in water extract with $\mathrm{pH}$ meter $(1: 10 \mathrm{w} / \mathrm{v})$. Cation exchange capacity was determined by ammonium acetate method (Thomas et al., 1982) and total nitrogen (TN) and phosphorus (TP) were measured by acid digestion method (Gao et al., 2015) and the extract samples were run on Continuous Flow-Analyzer (Bran and Luebbe AA3, Norderstedt, Germany). The biochar characteristics are presented in Table 1 .

\section{Experimental design}

Pot experiment was conducted between October - November 2019 (50 days) in a controlled greenhouse of Farmland Irrigation Research Institute, CAAS China. The experiment consisted of 5 treatments with 3 replications. There were two control treatments, without biochar and salt $(\mathrm{CK})$, the other one with no biochar and $1 \%(5 \mathrm{~g}$ $\mathrm{NaCl}$ ) salt stress (WB0: $0+1 \%$ ), while three levels of WB 15, 30, and $45 \mathrm{~g} \mathrm{~kg}^{-1}$ referred as $\mathrm{WB} 1, \mathrm{WB} 2$, and $\mathrm{WB} 3$, respectively, were used against $1 \%(5 \mathrm{~g})$ salt stress. The $1 \%$ of salt (w/w, $5 \mathrm{~g} / 5 \mathrm{~kg}$ of soil) was used which is equal to $11.3 \mathrm{dS} \mathrm{m}{ }^{-1}$. The $5 \mathrm{~kg}$ soil was 
thoroughly mixed with the aforementioned levels of biochar and filled in plastic pots having the size $15 \mathrm{~cm}$ width and $20 \mathrm{~cm}$ height. The pots were arranged in randomized design in controlled greenhouse maintained at $25 / 17^{\circ} \mathrm{C}$ day/night temperature (Ferreira et al., 2018) under natural illumination for $14 / 10 \mathrm{~h}$. Initially soil was irrigated once with salt water and left for field capacity. The seeds of local spinach variety Chunqiu were disinfected with $30 \% \mathrm{H}_{2} \mathrm{O}_{2}$ for ten minutes (Zama et al., 2018) and five seeds were sown in each pot. Thinning was done one week after germination to keep one spinach plant in each pot for further experiment. The recommended dose of NPK fertilizers, 100-75-75 was applied in the form of urea, single superphosphate, and sulphate of potash as basal. The pots were maintained at $60 \%$ water holding capacity throughout experiment.

\section{Observations before harvest}

Two days before harvest (48 days after sowing), plant physiological parameters such as photosynthesis rate $(P n)$, stomatal conductance $(G s)$, transpiration rate $(T r)$, and concentration of intracellular $\mathrm{CO}_{2}(\mathrm{Ci})$ were measured from fully expanded flag leaf by using portable photosynthesis system (Li-Cor-6400 LincoIn, NE, USA) between 9:00 am to $12: 00 \mathrm{pm}$. During measurements, reference $\mathrm{CO}_{2}$ concentration was equilibrated to $400 \mu \mathrm{mol} \mathrm{mol}{ }^{-1}$ with a $\mathrm{CO}_{2}$ mixture and the light adjusted at a PAR of $1200 \mu \mathrm{mol} \mathrm{m} \mathrm{m}^{-2}$. The block temperature was fixed at $25{ }^{\circ} \mathrm{C}$, the leaf-to-air vapour pressure deficit (VPD) was equilibrated between 1.5 and $2.0 \mathrm{kPa}$, and the flow was fixed at $300 \mu \mathrm{mol} \mathrm{s}^{-1}$. Chlorophyll fluorescence was measured on the same leaves and same day by fluoremeter (MINI-PAM-II; Heinz Walz, Effeltrich, Germany). The maximal photochemical efficiency of photosystem (Fv/Fm) was measured after leaves adapted in dark for 30 minutes.

\section{Plant growth attributes}

Plants were harvested 50 days after sowing with sharp pair of scissors from the bottom and rinsed with distilled water. Immediately, fresh weight of above ground part was measured on digital weight balance, number of leaves per plant were counted manually and plant height was recorded by ruler. For dry weight, plants were placed in oven at $70{ }^{\circ} \mathrm{C}$ for 72 hours and re-weighed by using weight balance. The oven-dried mass was ground in pestle and mortar. The samples were analyzed for total NP using acid digestion method (Gao et al., 2015). In brief, for total NP, $15 \mathrm{mg}$ sample was digested using $5 \mathrm{ml}$ of $\mathrm{H}_{2} \mathrm{SO}_{4}$ for 3 hours until white fumes appeared. The suspension was filtered through filter paper and run on Continuous-Flow Analyzer (AA3, Bran and Luebbe, Norderstedt, Germany).

\section{Statistical analysis}

Statistical tests were performed using SPSS 23.0 (IBM Corporation, New York, NY, USA). One-way analysis of variance (ANOVA) was applied on spinach growth parameters, nutrient contents in its tissues and soil properties. The data are expressed as the mean $(n=3) \pm \mathrm{SE}$ (standard errors) and multiple comparison tests (Least Significant Difference, Tukey and Duncan) were performed at significance level $<0.05$. 


\section{Results}

\section{Effect of biochar on plant growth parameters}

Number of leaves in spinach were significantly affected by the addition of biochar under salinity stress (Table 2). A constant decrease in number of leaves was observed with an increasing level of biochar under saline condition. Biochar applied at $45 \mathrm{~g} \mathrm{~kg}^{-1}$ rate decreased number of leaves by $58.1 \%$ in WB3 compared to that of the CK.

Table 2. Effect of biochar on number of leaves (plant $\left.{ }^{-1}\right)$, plant height (cm), fresh and dry weight $\left(g\right.$ plant $\left.^{-1}\right)$ under saline condition. Data are mean \pm standard error. Different alphabets represent significant differences $(p<0.05)$

\begin{tabular}{c|c|c|c|c}
\hline Biochar rate & $\begin{array}{c}\text { Number of leaves } \\
\left(\text { plant }^{-1}\right)\end{array}$ & $\begin{array}{c}\text { Plant height } \\
(\mathbf{c m})\end{array}$ & $\begin{array}{c}\text { Fresh weight } \\
\left(\text { g plant }^{-1}\right)\end{array}$ & $\begin{array}{c}\text { Dry Weight } \\
\left(\text { g plant }^{-1}\right)\end{array}$ \\
\hline CK & $10.3 \pm 0.9 \mathrm{a}$ & $21.3 \pm 1.2 \mathrm{a}$ & $9.27 \pm 0.54 \mathrm{a}$ & $0.87 \pm 0.02 \mathrm{a}$ \\
WB0 & $6.7 \pm 0.3 \mathrm{~b}$ & $12.7 \pm 1.7 \mathrm{bc}$ & $1.83 \pm 0.35 \mathrm{~b}$ & $0.17 \pm 0.01 \mathrm{c}$ \\
WB1 & $6.3 \pm 0.3 \mathrm{bc}$ & $15.7 \pm 1.2 \mathrm{~b}$ & $2.87 \pm 0.69 \mathrm{~b}$ & $0.28 \pm 0.03 \mathrm{~b}$ \\
WB2 & $6.7 \pm 0.7 \mathrm{~b}$ & $14.0 \pm 2.1 \mathrm{bc}$ & $2.37 \pm 0.32 \mathrm{~b}$ & $0.22 \pm 0.02 \mathrm{bc}$ \\
WB3 & $4.3 \pm 0.9 \mathrm{c}$ & $10.0 \pm 1.2 \mathrm{c}$ & $1.60 \pm 0.29 \mathrm{~b}$ & $0.16 \pm 0.03 \mathrm{bc}$ \\
\hline
\end{tabular}

$\mathrm{n}=3$

Plant height was significantly influenced by the application of biochar under saline condition (Table 2). Increasing the rate of biochar decreased plant height as compared to CK. Plant height decreased by $113.3 \%$ in WB3 with the addition of biochar as compared to CK. Statistically no significant differences were observed among the biochar treated plants. Among biochar treated plants, WB1 showed the highest plant height $(15.7 \mathrm{~cm})$ followed by WB2 $(14.0 \mathrm{~cm})$ and WB0 $(12.7 \mathrm{~cm})$ when compared to salt treated plants (WB0).

Spinach fresh and dry weights were significantly affected by biochar and salt stress (Table 2). The increasing rate of biochar decreased 2.87, 2.37 and $1.60 \mathrm{~g} \mathrm{plant}^{-1}$ fresh weight of spinach in WB1, WB2, and WB3 treatments, respectively compared to CK. FW weight decreased by $82.7 \%$ in WB3 when compared to CK. Whereas, similar trend was observed for dry weight. Biochar application decreased DW of spinach by $81.3 \%$ in WB3 compared with CK. No significant difference was noticed for fresh and dry weight among biochar and salt treated plants.

\section{Effect of biochar on gas exchange attributes}

The results regarding $P n, G s, C i$ and $T r$ are presented in Figure 1. Biochar application negatively affected $P n, G s, C i$, and $T r$ under saline condition over control. The $P n, G s, C i, T r$, and leaf fluorescence increased by $77.2,86.8,27.9$, and $27.3 \%$ in CK respectively over all biochar treated plants. The statistical data showed no difference among all the treatments including CK for leaf fluorescence (Fig. 2). The maximum reduction $(11.3 \%)$ for leaf fluorescence was observed in WB3. 

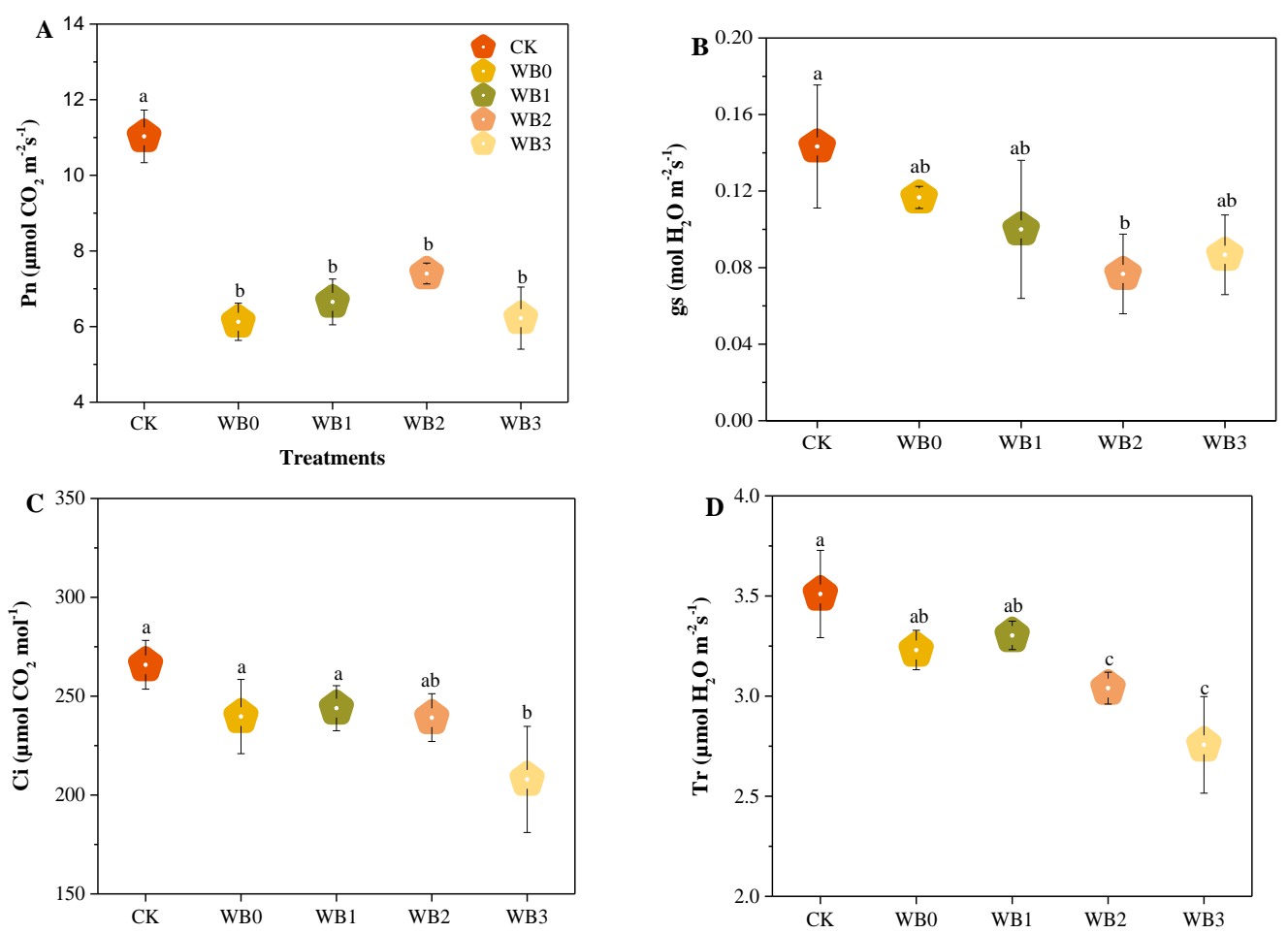

Figure 1. Impact of biochar on Pn, gs, Tr, and Ci under saline condition. A, B, C, and D respectively. Data are mean \pm standard error. Different alphabets on top of error bars represent significant differences $(p<0.05)$

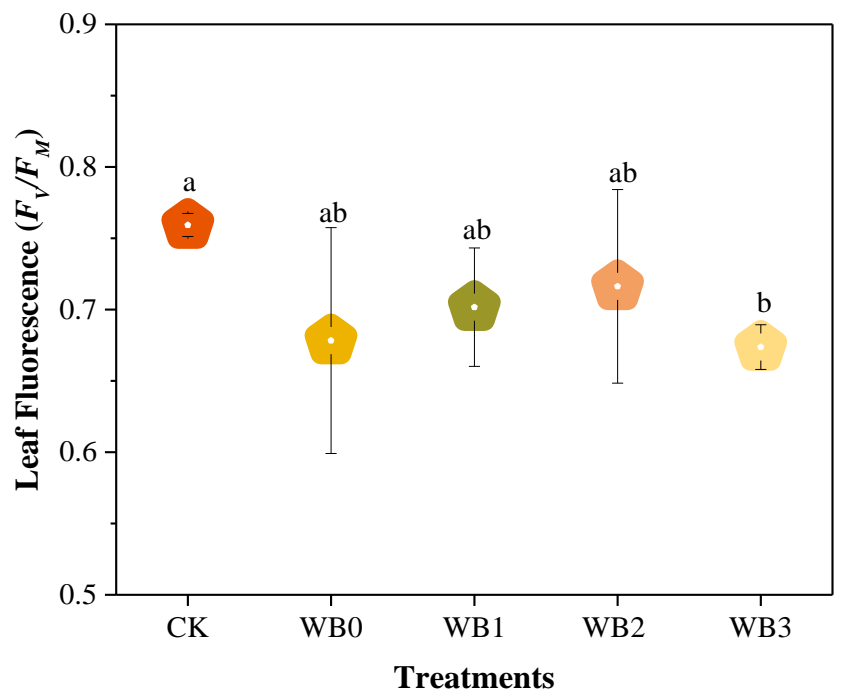

Figure 2. Impact of biochar on leaf fluorescence under saline condition. Data are mean \pm standard error. Different alphabets on top of error bars represent significant differences

$$
(p<0.05)
$$

\section{Effect of biochar on total nitrogen (TN) and phosphorus (TP) in spinach tissue}

The effect of biochar and salt stress on total $\mathrm{N}$ concentration in spinach tissues is shown in Figure 3. The results indicated that the increasing rate of biochar decreased 
TN concentration by $23.3,20.4$, and $15.6 \%$ in WB3, WB2, and WB1, respectively, compared to CK. Statistically, no significant difference was noticed for N concentration among the biochar treated and salt treated plants.

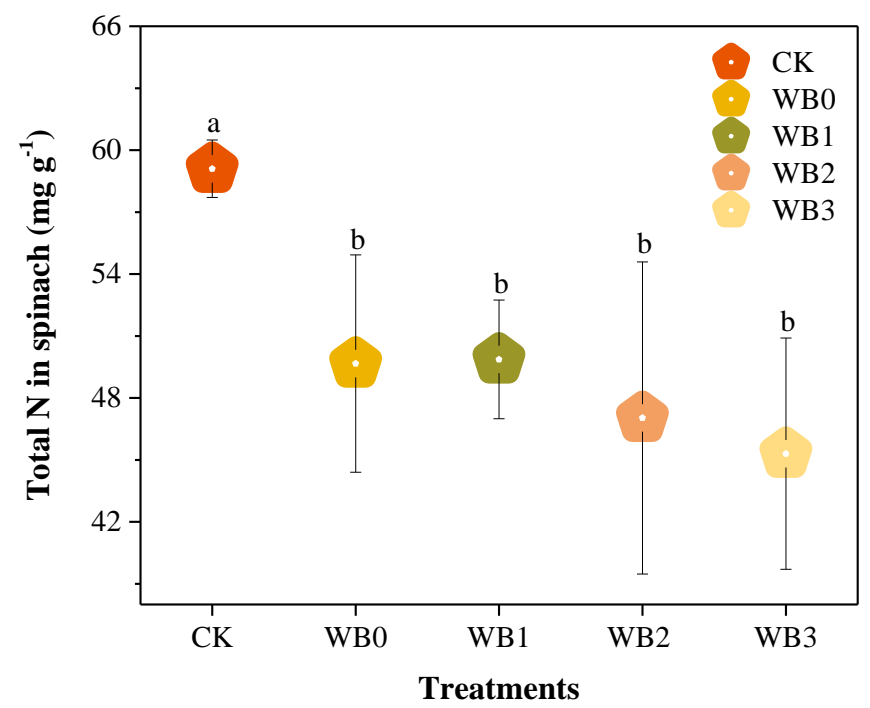

Figure 3. Impact of biochar on total nitrogen $\left(\mathrm{mg} \mathrm{g}^{-1}\right)$ in spinach tissue under saline condition. Data are mean \pm standard error. Different alphabets on top of error bars represent significant differences $(p<0.05)$

The observed values for TP concentration were different than other parameters as given in Figure 4. TP concentration in spinach tissues increased with increasing biochar application. TP concentration increased by $93.8 \%$ in WB3 followed by $66.2 \%$ and $27.1 \%$ in WB2 and WB1, respectively, when compared to CK.

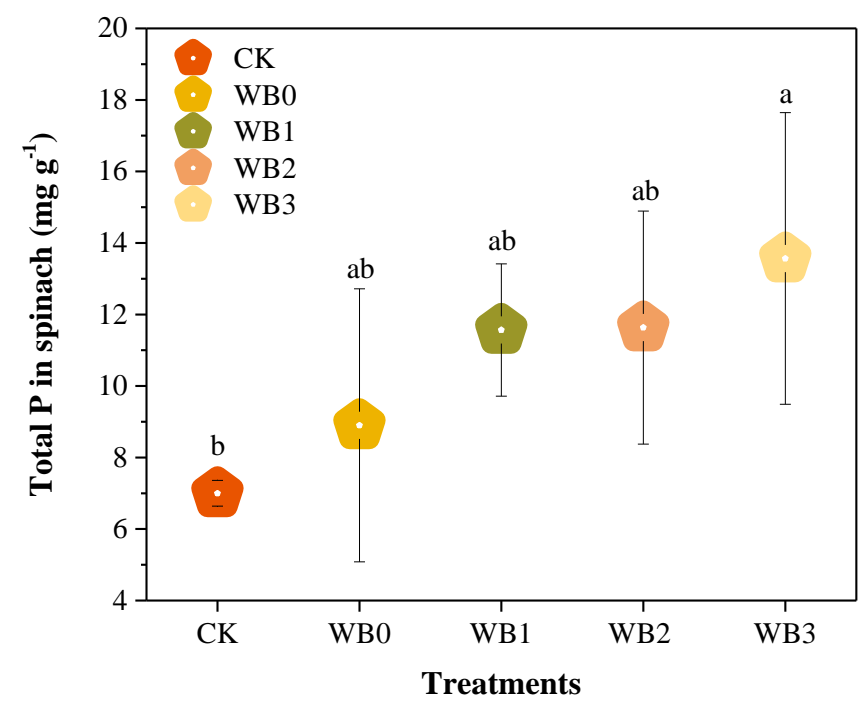

Figure 4. Impact of biochar on total phosphorus $\left(\mathrm{mg} \mathrm{g}^{-1}\right)$ in spinach tissue under saline condition. Data are mean \pm standard error. Different alphabets on top of error bars represent significant differences $(p<0.05)$. 


\section{Effect of biochar on soil properties}

Soil $\mathrm{pH}$ significantly influenced by addition of different biochar levels under saline condition (Table 3). Increasing the rate of biochar decreased soil $\mathrm{pH}$. Soil $\mathrm{pH}$ was decreased (7.63) at highest rate of biochar in WB3 compared to CK (8.51), followed by 8.05, 8.30 and 8.49 in WB2, WB1, and WB0, respectively.

Table 3. Effect of biochar on soil pH, electrical conductivity $\left(E C, \mathrm{mS} \mathrm{cm}^{-1}\right)$, total nitrogen (TN) and total phosphorus (TP) after harvest. Data are mean \pm standard error. Different alphabets represent significant differences $(p<0.05)$

\begin{tabular}{c|c|c|c|c}
\hline Biochar rate & $\mathbf{p H}$ & $\mathbf{E C}\left(\mathbf{m S ~ c m}^{-\mathbf{1}}\right)$ & $\mathbf{T N}\left(\mathbf{m g ~ g}^{-1}\right)$ & $\mathbf{T P}\left(\mathbf{m g ~ g}^{-1}\right)$ \\
\hline CK & $8.51 \pm 0.01 \mathrm{a}$ & $1.35 \pm 0.03 \mathrm{a}$ & $0.46 \pm 0.08 \mathrm{~b}$ & $0.63 \pm 0.02 \mathrm{~d}$ \\
WB0 & $8.49 \pm 0.01 \mathrm{a}$ & $1.51 \pm 0.01 \mathrm{a}$ & $0.42 \pm 0.01 \mathrm{~b}$ & $0.67 \pm 0.05 \mathrm{~d}$ \\
WB1 & $8.30 \pm 0.01 \mathrm{~b}$ & $1.34 \pm 0.02 \mathrm{~b}$ & $0.47 \pm 0.01 \mathrm{~b}$ & $1.49 \pm 0.09 \mathrm{c}$ \\
WB2 & $8.05 \pm 0.02 \mathrm{c}$ & $1.37 \pm 0.01 \mathrm{~b}$ & $0.51 \pm 0.04 \mathrm{ab}$ & $2.11 \pm 0.08 \mathrm{~b}$ \\
WB3 & $7.63 \pm 0.03 \mathrm{~d}$ & $1.54 \pm 0.02 \mathrm{~b}$ & $0.62 \pm 0.03 \mathrm{a}$ & $2.64 \pm 0.02 \mathrm{a}$ \\
\hline
\end{tabular}

$\mathrm{n}=3$

Soil EC was affected by biochar is shown in Table 3. The application of biochar increased soil EC $\left(1.54 \mathrm{mS} \mathrm{cm}^{-1}\right)$ in WB3 compared to CK $\left(1.35 \mathrm{mS} \mathrm{cm} \mathrm{cm}^{-1}\right)$. Soil EC increased with increasing rate of biochar $\left(1.34,137\right.$, and $1.54 \mathrm{mS} \mathrm{cm}^{-1}$ in WB1, WB2, and WB3), respectively.

Total $\mathrm{N}$ significantly increased in the soil where biochar was applied (Table 3). TN content increased by $34.5,10.1$, and $1.5 \%$ in $\mathrm{WB} 3, \mathrm{WB} 2$, and $\mathrm{WB} 1$ treatments respectively compared to $\mathrm{CK}$.

Soil TP was significantly influenced by biochar (Table 3 ) under saline condition. The results showed that TP in soil significantly increased by 317.4, 232.6, and $135.3 \%$ in WB3, WB2, and WB1 respectively, over CK.

\section{Discussion}

\section{Influence of biochar on spinach growth parameters}

Our experimental findings are different from the results of other studies that revealed positive effects of biochar on both plant growths under saline condition (Lashari et al., 2013; Gavili et al., 2018; Yu et al., 2018; Rezaei and Razzaghi, 2018; Huang et al., 2019). In contrast, negative effects of biochar have also been reported in various studies (Deenik et al., 2010; Hol et al., 2017; Kong et al., 2019). Number of leaves (plant ${ }^{-1}$ ), plant height $(\mathrm{cm})$ and plant fresh and dry weight were notably decreased by biochar under saline condition. The reduction in growth parameters might be due to the accumulation of excess salts $(\mathrm{Na}$ and $\mathrm{Cl})$ in root zone which causes toxicity for plants and/or the low $\mathrm{pH}$ of biochar caused reduction in physiological parameters. High concentration of $\mathrm{Na}^{+}$which disturbs physiological and biochemical processes in cells, results in growth reduction (Munns, 2002). A significant decrease in plant height, shoot and root biomass and nutrient uptake in different crops for example lettuce, sweet corn, wheat, peas under the application of biochar and salt in greenhouse and field 
experiments were also reported by Deenik et al. (2010). Decrease in plant fresh biomass due to the high concentration of salt which causes osmotic pressure and the availability of water is affected. Our findings are in agreement with the results of Hol et al. (2017), who conducted three greenhouse experiments, by using mown biochar. Their results indicated that biochar could not increase plant shoot and root biomass due to the soil biota. Water availability and sodium toxicity to plants cause reduction in shoot and dry mass (Farhangi-Arbiz, 2018). Low pH of biochar and salt stress may cause the lowering of water potential in the growth medium that reduces cell turgidity that retards cell division, expansion, elongation, and differentiation which ultimately reduces plant biomass (Mazher et al., 2007; Riffat and Ahmed, 2020). Another greenhouse study revealed that pine forest waste biochar initially decreased lettuce growth by increasing biochar rate (2-4\%). Gonzaga et al. (2018) conducted a greenhouse experiment on maize and observed that pinewood biochar did not increase shoot and root growth.

\section{Effect of biochar on gas exchange attributes}

Gas exchange parameters including $P n, G s, C i$, and $T r$ were affected by different biochar levels under salinity stress. The $P n$ is a biological process which enables plants to gain energy from sunlight (Yahia and Carrilo-Lopez, 2017). This energy is utilized for plant growth, development and adaptive responses to environmental conditions such as salt stress. Several studies have reported positive effect of biochar on $\mathrm{Pn}, \mathrm{Gs}, \mathrm{Ci}$, and Tr under saline condition (Akhtar et al., 2015; Huang et al., 2019). But the results of our study are opposite. Statistically, $P n, G s, C i$, and $T r$ were negatively affected by biochar under saline condition. Biochar and salt stress have negatively affected exchange parameters in all treatments. Because when plants uptake excess $\mathrm{Na}$, cells start to be plasmolyzed. Salt stress may affect the gas exchange in the plants. Salinity causes plasmolysis in plants and due to which transpiration rate decreases, which directly affects the exchange of $\mathrm{CO}_{2}$ and photosynthesis (Najar et al., 2018). Furthermore, our results are in confirmatory with Thomas et al. (2013) who reported in their glasshouse experiment and revealed that plants did not show a significant response for net photosynthesis to sawdust biochar under saline condition.

Leaf fluorescence is affected by accumulation of salts in root zone. The $20 \%$ biochar markedly decreased leaf fluorescence in bean seedling under saline condition (FarhangiArbiz et al., 2018). Similar results were observed in present study for leaf fluorescence among all the treatments. The leaf fluorescence was directly affected by the accumulation of salts in root zone and low uptake of nutrients.

\section{Effect of biochar on TN and TP in plant tissues}

Nitrogen and phosphorus are key elements for plant growth and development. Increasing rate of biochar caused a reduction in $\mathrm{N}$ concentration in spinach tissue. It directly affected plant growth parameters. But statistically no difference was noticed among other treatments where no biochar and salt were applied. The application of biochar along with salt may result in low nutrient supply and/or due to acidic nature of biochar which may cause low availability of $\mathrm{N}$ because of denitrification. It is reported in a study that the availability of $\mathrm{N}$ can greatly be influenced by low $\mathrm{pH}$ because the activity of bacteria is decreased at low pH (Ruan et al., 2007; Gonzaga et al., 2018; Neina, 2019). Deenik et al. (2010) reported in their greenhouse experiment on that increasing the quantity of nut shell charcoal decreased uptake of $\mathrm{N}$ in lettuce in a greenhouse experiment. 
In contrast, enhanced $\mathrm{P}$ was observed in tissues with increasing biochar level under saline condition. It is speculated that the possible reason for high concentration of $\mathrm{P}$ was observed in plant tissue is may be high concentration of $\mathrm{P}$ was recorded in biochar samples. Biochar is responsible for desorption which positively influences $\mathrm{P}$ uptake (Han et al., 2018). The acidic nature of biochar or soil may have played role for high uptake of $\mathrm{P}$ because different studies reported that $\mathrm{P}$ is mostly available to plants at low $\mathrm{pH}$ as well as $\mathrm{P}$ fixation is reduced at low $\mathrm{pH}$ because organic amendments have a high affinity for Al and Fe (Qi et al., 2017; Gonzaga et al., 2018). The results of our study also agreed with the results of Gonzaga et al. (2018), who noticed in their greenhouse experiment on maize that pinewood biochar increased $\mathrm{P}$ in maize plant tissue due to release of $\mathrm{P}$ under acidic soil.

\section{Effect of biochar on soil properties}

Soil $\mathrm{pH}$ and EC are two main chemical properties of soil and nutrients availability is also depending upon soil $\mathrm{pH}$. Soil $\mathrm{pH}$ was significantly decreased with the addition of increased biochar. This decrease in soil $\mathrm{pH}$ is may be the result of strongly acidic wood biochar $(\mathrm{pH}$ 2.52). The release of acidic functional groups during the oxidation of functional groups of biochar can cause low soil pH (Cheng et al., 2006). Similar results were obtained by Ippolito et al. (2016), who applied shaving wood biochar having $\mathrm{pH}$ 5.8 , decreased $\mathrm{pH}$ of calcareous soil in a pot experiment.

The EC of soil was increased with the increase of salt and biochar as compared to control. The possible reason for high EC in soil is may be the soil treated with high salt concentration. The results of our study confirm the findings of Novak et al. (2018), who discovered increase in soil EC due to the addition of lime along with miscanthus biochar.

Nitrogen is major element necessary for plant growth and yield. Comparing biochar with the soil, used in experiment, biochar had 4.6 times more $\mathrm{N}$ than soil. We noticed that soil $\mathrm{N}$ increased in the spots where higher rate of biochar was applied. The reason for high $\mathrm{N}$ content in soil may be the low availability of $\mathrm{N}$ to plants from biochar. Biochar contains high nutrients because of its organic origin and its addition to soil enhances in soil N (Duarte et al., 2019) because this increase can be associated with specific surface area that can contribute to the nitrogen amount in the soil. The findings of our study are in agreement with the results of Deenik et al. (2010), who observed that biochar addition increased soil $\mathrm{N}$ as compared to control.

Total phosphorus enhanced in soil with increasing rate of biochar as compared to the biochar untreated soils. The reason for high biochar in soil is the high concentration of $\mathrm{P}$ in biochar and easy release due to acidic nature of biochar. Biochar addition to acidic soil is expected to reduce $\mathrm{P}$ fixation because organic amendments have affinity for Al and Fe (Gonzaga et al., 2018).

\section{Conclusion}

The present study clearly indicated that none of the biochar levels was effective on spinach growth indicators $(P n, G s, C i$, and $T r$ and plant height, number of leaves, fresh and dry weight and nitrogen concentration) under saline condition. In addition, it was noticed that $\mathrm{P}$ concentration was more in biochar treated plants than other treatments. Along with negative effects of biochar on spinach growth at the same time it improved soil properties. For example, soil $\mathrm{pH}$ was significantly decreased when biochar was 
applied at the rate of $45 \mathrm{~g} \mathrm{~kg}^{-1}$, soil EC was slightly increased and soil nutritional properties (TN and TP) were significantly improved by increasing the rate of biochar application in soil. TN and TP increased by 34.5 and $317.4 \%$ in soil with the maximum level of applied biochar. Hence, we suggest that further studies should be conducted to evaluate the effect of acidic biohcar on field crops and soil properties.

Acknowledgements. The Authors would like to express appreciation to the Natural Science Foundation of China (No. 51790534) and Chinese Scholarship Council.

\section{REFERENCES}

[1] Agbna, G. H. D., Dongli, S., Zhipeng, L., Elshaikh, N. A., Guangcheng, S., Timm, L. C. (2017): Effects of deficit irrigation and biochar addition on the growth, yield, and quality of tomato. - Science Horticulturae 222: 90-101.

[2] Ahmad, P., Latef, A. A. A., Hashem, A., Abd-Allah, E. F., Gucel, S., Tran, L. S. P. (2016): Nitric oxide mitigates salt stress by regulating levels of osmolytes and antioxidant enzymes in chickpea. - Frontier Plant Science 7: 347.

[3] Akhtar, S. S., Andersen, M. N., Liu, F. (2015): Residual effects of biochar on improving growth, physiology and yield of wheat under salt stress. - Agricultural Water Management 158: 61-68.

[4] Alagoz, S. M., Toorchi, M. (2018): An investigation of some key morpho-physiological attributes and leaf proteome profile in canola (Brassica napus L.) under salinity stress. Pakistan Journal of Botany 50(3): 847-852.

[5] Amini, S., Ghadiri, H., Chen, C., Marschner, P. (2016): Salt-affected soils, reclamation, carbon dynamics, and biochar: A review. - Journal of Soils and Sediments 16: 939-953.

[6] Bouyoucos, G. J. (1962): Hydrometer Method Improved for Making Particle Size Analysis of Soils. - Agronomy Journal 54: 464-465.

[7] Caparrotta, S., Masi, E., Atzori, G., Diamanti, I., Azzarello, E., Mancuso, S., Pandolfi, C. (2019): Growing spinach (Spinacia oleracea L.) with different seawater concentrations: Effects on fresh, boiled and steamed leaves. - Scientia Horticulturae 256: 108540108546.

[8] Cheng, C. H., Lehmann, J., Thies, J. E., Burton, S. D., Engelhard, M. H. (2006): Oxidation of black carbon by biotic and abiotic processes. - Organic Geochemistry 37: 1477-1488.

[9] Danish, S., Muhammad, Z. H., Fahad, S., Saud, S., Brtnicky, M., Hammerschmiedt, T., Datta, R. (2020): Drought stress alleviation by ACC deaminase producing Achromobacter xylosoxidant and Enterobacter cloacae, with and without timber waster biochar in maize. - Sustainability 12: 1-17.

[10] Deenik, J. L., Uehara, T. M. G., Antal Jr., M. J., Campbell, S. (2010): Charcoal volatile matter content influences plant growth and soil nitrogen transformations. - Soil Science Society of American Journal 74: 1259-1270.

[11] Dicoteau, D. R. (2000): Vegetable crops. - Prentice Hall, New Jersey, USA.

[12] Ding, Z., Kheir, A. M. S., Ali, M. G. A., Ali, O. A. M., Abdelaal, A. I. N., Lin, X., Zhou, Z., Wang, B., Liu, B., He, Z. (2020): The integrated effect of salinity, organic amendments, phosphorus fertilizers, and deficit irrigation on soil properties, phosphorus fractionation and wheat productivity. - Scientific Reports 10: 2736-2748.

[13] Duarte, S. J., Glaser, B., Cerri, C. E. P. (2019): Effect of biochar particle size on physical, hydrological and chemical properties of loamy and sandy tropical soils. - Agronomy 9: 165-180. 
[14] Farhangi-Abriz, S., Torabian, S. (2018): Antioxidant enzyme and osmotic adjustment changes in bean seedlings as affected by biochar under salt stress. - Ecotoxicology and Environmental Safety 137: 64-70.

[15] Ferreira, J. F. S., Sandhu, D., Liu, X., Halvorson, J. J. (2018): Spinach (Spinacea oleracea L.) response to salinity: nutritional value, physiological parameters, antioxidant capacity, and gene expression. - Agriculture 8: 163-179.

[16] Filho, F. G., Dias, N. S., Suddarth, S. R. P., Ferreira, J. S. F., Anderson, R. G., Fernandes, C. S., Lira, R. B., Neto, M. F., Cosme, C. R. (2019): Reclaiming tropical saline-sodic soils with gypsum and cow manure. - Water 12: 57-69.

[17] Gao, H., Mao, H., Zhang, X. (2015): Determination of lettuce nitrogen content using spectroscopy with efficient wavelength selection and extreme learning machine. Zemdirbyste-Agriculture 102(1): 51-58.

[18] Gavili, E., Moosavi, A. A., Choghamarani, F. M. (2018): Cattle manure biochar potential for ameliorating soil physical characteristics and spinach response under drought. Archives of Agronomy and Soil Science 64(12): 1714-1727.

[19] Glab, T., Palmowska, J., Zaleski, T., Gondek, K. (2016): Effect of biochar application on soil hydrological properties and physical quality of sandy soil. - Geoderma 281: 11-20.

[20] Gonzaga, M. I. S., Mackowiak, C., de Almeida, A. Q., de Carvalho Junior, J. I. T., Andrade, K. R. (2018): Positive and negative effects of biochar from coconut husks, orange bagasse and pine wood chips on maize (Zea mays L.) growth and nutrition. Catena 162: 414-420.

[21] Hamouda, I., Badri, M., Mejri, M., Cruz, C., Siddique, K., Hessini, K. (2015): Salt tolerance of Betamacrocarpa is associated with efficient osmotic adjustment and increased apoplastic water content. - Plant Biology 18: 369-375.

[22] Han, Y., Choi, B., Chen, X. (2018): Adsorption and desorption of phosphorus in biocharamended black soil as affected by freeze-thaw cycles in Northeast China. - Sustainability 10: $1573-1583$.

[23] Hol, W. H. G., Vestergard, M., Hooven, F., Duyts, H., Voorde, T. F. J., Bezemer, T. M. (2017): Transient negative biochar effects on plant growth are strongest after microbial species loss. - Soil Biology and Biochemistry 115: 442-451.

[24] Huang, M., Zhang, Z., Zhai, Y., Lu, P., Zhu, C. (2019): Effect of straw biochar on soil properties and wheat production under saline water irrigation. - Agronomy 9: 456-472.

[25] Ippolito, J. A., Ducey, T. F., Cantrell, K. B., Novak, J. M., Lentz, R. D. (2016): Designer, acidic biochar influences calcareous soil characteristics. - Chemosphere 142: 184-191.

[26] Kong, L., Liu, J., Zhou, Q., Sun, Z., Ma, Z. (2019): Sewage sludge derived biochars provoke negative effects on wheat growth related to the PTEs. - Biochemical Engineering Journal 152: 1-8.

[27] Lashari, M. S., Liu, Y., Li, L., Pan, W., Fu, J., Pan, G., Zheng, J., Zheng, J., Zhang, X., $\mathrm{Yu}, \mathrm{X}$. (2013): Effects of amendment of biochar-manure compost in conjunction with pyroligneous solution on soil quality and wheat yield of a salt-stressed cropland from Central China Great Plain. - Field Crops Research 144: 113-118.

[28] Lehman, J., Joseph, S. (2009): Biochar for environmental management science and technology. - Earthscan, USA.

[29] Li, H., Ye, X., Geng, Z., Zhou, H., Guo, X., Zhang, Y., Zhao, H., Wang, G. (2016): The influence of biochar type on long-term stabilization for $\mathrm{Cd}$ and $\mathrm{Cu}$ in contaminated paddy soils. - Journal of Hazard Material 304: 40-48.

[30] Maksimovic, I., Ilin, Z. (2012): Effects of salinity on vegetable growth and nutrient uptake. - In: Irrigation System and Practices Challenging Environment, pp. 169-190.

[31] Mazher, A. M. A., El-Quesni, E. M. F., Farahat, M. M. (2007): Responses of ornamental and woody trees to salinity. - World Journal of Agricultural Sciences 3: 386-395.

[32] Min, W., Guo, H., Zhou, G., Zhang, W., Ma, L., Ye, J., Hou, Z., Wu, L. (2016): Soil salinity, leaching, and cotton growth as affected by saline water drip irrigation and $\mathrm{N}$ fertigation. - Soil and Plant Science 66(6): 489-501. 
[33] Munns, R. (2002): Comparative physiology of salt and water stress. - Plant Cell Environnent 25: 239-250.

[34] Najar, R., Aydi, S., Sassi-Aydi, S., Zarai, A., Adelly, C. (2018): Effect of salt stress on photosynthesis and chlorophyll fluorescence in Medicago truncatula. - Plant Biosystems: 153(1): 88-97.

[35] Neina, D. (2019): The role of soil pH in plant nutrition and soil remediation. - Applied and Environmental Soil Science, DOI: 10.1155/2019/5794869.

[36] Novak, J. M., Ippolito, J. A., Ducey, T. F., Watts, D. W., Spokas, K. A., Trippe, K. M., Sigua, G. C., Johnson, M. G. (2018): Remediation of an acidic mine spoil: Miscanthus biochar and lime amendment affects metal availability, plant growth and soil enzyme activity. - Chemosphere 205: 709-718.

[37] Ors, S., Suarez, D. L. (2016): Salt tolerance of spinach as related to seasonal climate. Horticulture Scientia 43(1): 33-41.

[38] Piash, M. I., Hossain, M. F., Parveen, Z. (2019): Effect of biochar and fertilizer application on the growth and nutrient accumulation of rice and vegetables in two contrast soils. - Acta Scientific Agriculture 3(2): 74-83.

[39] Qi, F., Dong, Z., Lamb, D., Naidu, R., Bolan, N. S., Ok, Y. S., Liu, C., Khan, N., Johir, M. A. H., Semple, K. T. (2017): Effect of acidic and neutral biochars on properties and cadmium retention of soils. - Chemosphere 180: 564-573.

[40] Ratnakar, A., Rai, A. (2013): Alleviation of the effects of $\mathrm{NaCl}$ salinity in spinach (Spinacia oleracea L. var All green) using plant growth regulators. - Journal of Stress Physiology and Biochemistry 9(3): 122-128.

[41] Rayment, G. E., Higginson, F. R. (1992): Australian Laboratory Handbook of Soil and Water Chemical Methods. - Inkata Press, Melbourne.

[42] Rezaei, N., Razzaghi, F. (2018): Effect of different levels of water salinity and biochar on wheat yield under greenhouse conditions. - Acta Horticulture 1190: 83-88.

[43] Riffat, A., Ahmad, M. S. A. (2016): Regulation of antioxidant activity in maize (Zea mays L.) by exogenous application of sulfur under saline conditions. - Turkish Journal of Botany 44: 62-75.

[44] Ruan, J., Gerendás, J., Hardter, R., Sattelmacher, B. (2007): Effect of nitrogen form and root-zone $\mathrm{pH}$ on growth and nitrogen uptake of tea (Camellia sinensis) plants. - Analysis of Botany 99(2): 301-310.

[45] Thomas, G. W. (1982): Exchangeable cations. - In: Page, A. L., Miller, R. H., Keeney, D. R. (eds.) Methods of soil analysis, $2^{\text {nd }}$ ed. Chemical and microbiological properties. American Society of Agronomy Incharge, Madison, pp. 159-165.

[46] Thomas, S. C., Frye, S., Gale, N., Garmon, M., Launchbury, R., Machado, N., Melamed, S., Murray, J., Petroff, A., Winsborough, C. (2013): Biochar mitigates negative effects of salt addition on two herbaceous plant species. - Journal of Environmental Management 129: 62-68.

[47] Unlukara, A. T. Y., Cemek, B. (2017): Effects of Irrigation water salinity on evapotranspiration and spinach (Spinacia oleracea L. Matador) plant parameters in greenhouse indoor and outdoor conditions. - Agronomy Research 15(5): 2183-2194.

[48] Wichern, F., Islam, M. R., Hemkemeyer, M., Watson, C., Joergensen, R. G. (2020): Organic amendments alleviate salinity effects on soil microorganisms and mineralization processes in aerobic and anaerobic paddy rice soils. - Frontiers in Sustainable Food Systems 4: 1-14.

[49] Xu, C., Mou, B. (2016): Response of spinach to salinity and nutrient deficiency in growth, physiology and nutritional value. - Journal of American Society of Horticultural Science 141(1): 1-10.

[50] Yahia, E. M., Carrillo-Lopez, A. (2017): Postharvest physiology and biochemistry of fruits and vegetables. - Wood Head Publishing.

[51] Yan, N., Marschner, P., Cao, W., Zuo, C., Qin, W. (2015): Influence of salinity and water content on soil microorganisms. - International Soil Water Conservation 3: 316-323. 
[52] Yang, Z., Li, J. L., Liu, L. N., Xie, Q., Sui, N. (2020): Photosynthetic regulation under salt stress and salt-tolerance mechanism of sweet sorghum. - Frontier Plant Science 10: $1722-1734$.

[53] Younis, U., Athar, M., Malik, S. A., Shah, M. H. R., Mahmood, S. (2015): Biochar impact on physiological and biochemical attributes of spinach (Spinacia oleracea L.) in nickel contaminated soil. - Global Journal of Environmental Science Management 1(3): 245-254.

[54] Yu, C. H., Wang, S. L., Tongsiri, P., Cheng, M. P., Lai, H. Y. (2018): Effects of poultrylitter biochar on soil properties and growth of water spinach (Ipomoea aquatica Forsk.). Sustainability 10: 2536-2554.

[55] Zama, E. F., Reid, B. J., Sun, G. X., Yuan, H. Y., Li, X. M., Zhu, Y. G. (2018): Silicon (Si) biochar for the mitigation of arsenic (As) bioaccumulation in spinach (Spinacia oleracea) and improvement in the plant growth. - Journal of Cleaner Production 189: 386-395.

[56] Zhang, M., Fan, Y., Ji, Y., Jiang, Z., Wang, L. (2013): Effect of salt stress on ion content, antioxidant enzymes and protein profile in different tissues of Broussonetia papyrifera. South African Journal of Botany 85: 1-9.

[57] Zhu, J. K. (2003): Regulation of ion homeostasis under salt stress. - Current Opinion Plant Biology 6: 441-445.

[58] Zorb, C., Geilfus, C. M., Dietz, K. J. (2018): Salinity and Crop yield. - Plant Biology 21(1): 31-38. 